\title{
Besedje za bratranca in sestrično v slovenskih narečjih (po gradivu za SLA)
}

\author{
Tjaša Jakop (Ljubljana)
}

IZVLEČEK: V članku je z metodo lingvistične geografije predstavljeno besedje, ki v slovenskih narečjih poimenuje sorodstvena razmerja, in sicer tetine ali stričeve otroke. V vprašalnici za Slovenski lingvistični atlas (SLA) sta v XIII. poglavju Družina tudi vprašanji št. 626 (bratranec) in št. 627 (sestrična), katerih raznoliki odgovori so prikazani na leksično-besedotvornih kartah.

ABSTRACT: This article uses linguistic geography to present vocabulary denoting blood relationships in Slovenian dialects; specifically, the children of aunts and uncles. Section thirteen of the SLA questionnaire titled "Family" also includes questions 626 (bratranec 'male cousin') and 627 (sestrična 'female cousin'). The various answers to these questions are presented on lexical and word-formative maps.

\section{Uvod}

Poimenovanja za ožje sorodstvene vezi so po slovenskih narečjih leksikološko dokaj enotna, z morebitnimi vplivi sosednjih jezikov (zlasti na zahodu). Najenotnejša so poimenovanja za pomen oče (V604) in mati (V605), sin (V606) in hči (V607) ter brat (V620) in sestra (V621), medtem ko se poimenovanja bratranec (V626) in sestrična (V627) že bolj pokrajinsko razlikujejo.

\section{Gradivo}

Pogostnost in prostorska razširjenost poimenovanj bratranec in sestrična je razvidna z jezikovnih kart s pripadajočima legendama. Karti sta napisno-izoglosno-znakovni, z legendo $\mathrm{v}$ desnem kotu spodaj. Znake obeh kart sem slušala čim bolj uskladiti, da bi bila njuna primerjava preglednejša. Notranje modifikacije znakov kažejo na različne pone, zunanja modifikacija pa pove, da gre za večbesedno poimenovanje (npr. mali brat). Nezapolnjenost znaka kaže, da je leksem prevzet. Pri točkah, ki še vedno niso zapisane, je namesto znaka številka kraja podčrtana 
(npr. 14), manjkajoči odgovori sicer zapisanih točk pa so označeni s poševnico (/). Diferenciranost leksemov in tujejezikovni vplivi so obdelani v komentarjih. ${ }^{1}$

Pri kartografiranju leksike je potrebno gradivo poknjižiti, tj. poiskati pravo stopnjo oz. mero abstrakcije, pri čemer se upošteva glasovne zakone posameznega govora (kot npr. popolna redukcija nenaglašenih samoglasnikov). ${ }^{2}$ Pri tem so nam $\mathrm{v}$ pomoč fonološki opisi posameznih govorov, katerih število se iz leta v leto veča (trenutno je od 404 točk oz. govorov SLA narejenih že 41 fonoloških opisov). Besede je potrebno tudi etimološko in besedotvorno razčleniti.

\section{Izvor in pomen leksemov}

Leksem bratránec (bratránka 'sestrična') je soroden ali enak cslovan. bratanı 'bratov sin, nečak, bratov vnuk', star. hrv. bràtan 'bratov sin', češ. bratranec 'bratranec'. V praslovanščini sta za koren brat- obstajali še obe obliki: bratrb in (po disimilacijski izgubi -r) bratb. Pslovan. *braträns je izpeljanka iz *bra̋trı 'brat', kar je prvotno pomenilo *'bratov sin, nečak'. Pridana pripona -an označuje specifikacijo v krvnem sorodstvu (bratan, bratana). Ta pomen se dobi tudi z razširitvijo s pomanjševalno pripono -ec (brat(r)anec) ali -ka (bratranka) ali pa pripono -ič (bratič, sestrič). Leksema bratran(ec) in bratan(ec) torej izhajata iz dveh različnih osnov, katerima je pridana pripona -an.

Današnji pomen 'stričev (ali tetin) sin' je nastal tako, da so to sorodstveno oznako otroci prevzeli od svojih staršev. Prvotni pomen se (poleg v zgoraj naštetih slovanskih primerih) ohranja še v redko rabljenem sloven. bratän 'bratov sin, nečak', bratána ali bratrána 'bratova hči, nečakinja'. Enako je iz séstra tvorjeno danes redko rabljeno sestrânec 'bratranec (prvotno po očetovi ali mamini sestri)', sestrána 'sestrična'. V etimoloških slovarjih najdemo še različice brâtič, brátranec, bratânec, bratrânček; sestrîčnik, sestrînec, sestrînek, séstrnik, sestrânič.

Leksem sestrîčna s pomenom 'sestrina hči' je v ženskem spolu posamostaljeni pridevnik od sestríca, manjšalnice od séstra. Iz manjšalnice moškega spola je sloven. sestrïč 'sestrin sin, nečak' (16. stol.) < *sestrît'b. Sestrîčna je bila torej prvotno *'sestrina hči, nečakinja'. Današnji pomen 'stričeva (ali tetina) hči' je nastal tako, da so to sorodstveno oznako otroci prevzeli od svojih staršev in pri tem niso upoštevali spremembe sorodstvenega razmerja (kot v primeru bratránec). Enako je iz brät tvorjeno danes redko rabljeno bratǐc 'bratranec (prvotno po očetovem ali maminem bratu)', bratîčna ali bratrîčna 'bratova hči, nečakinja'. Različice so še: séstrna, séstrnica, sestrîčka.

Leksem str̂nič je nastal iz *strъjb-nî́čb s pomenom 'stričev sin', posamostaljeno

1 Pri fonetičnem zapisu je uporabljena pisava ZRCola, ki jo je na Znanstvenoraziskovalnem centru SAZU v Ljubljani (http://www.zrc-sazu.si) razvil Peter Weiss, na kartah pa znaki SIMBola. Gradivo je vneseno s programom SlovarRed, karte pa narejene s programom CorelDraw.

2 Čeprav imata Pleteršnik in Bezlaj v slovarjih zapisani obe naglasni različici (brátranəc in bratânəc), prav tako tudi SSKJ (brátranec tudi bratránec), na karti št. 1 (V626) mesto naglasa ni posebej označeno. 
iz pridevnika *strъjb-nb 'stričev' (stryjb-na(ja) 'stričeva' $\rightarrow$ strina). ${ }^{3}$ Strnič, strénič in strnična so izrazi, ki se uporabljajo v slovenski Istri, le na jugu se mešajo z zermanom in zermano. ${ }^{4} \mathrm{~V}$ (etimoloških) slovarjih ne najdemo naslednjih leksemov, ki se nahajajo v gradivu SLA: bratran (le bratan), sestričen, sestranica, sestrinka, bratrančka in bratrančinja (le bratranka), kar kaže na izredno bogastvo slovenskega narečnega besedotvorja.

Od neslovanskih izrazov najdemo v gradivu SLA naslednje prevzete besede: $\mathrm{Na}$ zahodu najdemo romanske sposojenke kužin, kužina (< it. cugino) 'bratranec, sestrična', kusen, kusena ( $<$ furl. in ben. cusìn) 'bratranec, sestrična'5 in zurman, zurmana $^{6}$ ( $<$ furl. in ben. zermàn '1. bratranec, 2. sorodnik iste generacije, 3. star družinski prijatelj (Istra))' [v furl. je bila verjetno prevzeta iz fr. le cousin germain 'prvi bratranec', la cousine germaine 'prva sestrična']. Na vzhodu najdemo madžarsko sposojenko unokateštver $(<\operatorname{madž}$. unokatestvér = skupno ime za bratrance, sestrične, nečake, nečakinje, vnuke in vnukinje, otroke bratov in sester (ponekod v Porabju) ${ }^{7}$ ([madž. barát ima drug pomen, in sicer 'prijatelj'].

\section{Razširjenost leksemov v slovenskih narečjih (komentar h kartam)}

Najbolj razširjen leksem v pomenu 'stričev ali tetin sin' je bratranec, v pomenu 'stričeva ali tetina hči' pa sestrična. Leksema najdemo v vseh narečnih skupinah: $\mathrm{v}$ celotni koroški narečni skupini, v vzhodnem delu primorske narečne skupine (brez rezijanskega, terskega, nadiškega, briškega, istrskega in dela kraškega in notranjskega narečja), v celotni rovtarski, dolenjski in gorenjski narečni skupini, v štajerski narečni skupini (razen v južnem delu kozjansko-bizeljskega in južnopohorskega narečja). $V$ panonski narečni skupini prevladuje poimenovanje bratranec, namesto leksema sestrična pa se pogosteje rabi leksem sestrana oz. sestranica, le v eni točki haloškega narečja pa sestrinka.

Različico brez - $r$ - bratanec poznajo le na vzhodu: $\mathrm{v}$ panonskem prleškem in zahodnem delu prekmurskega narečja. Oblike brez pripone -ec so še redkejše; bratran poznajo le kot različico $\mathrm{v}$ točki rovtarskega baškega govora in točki vzhodnogorenjskega govora gorenjske narečne skupine, v točki zgornjesavinjskega in dveh točkah srednjesavinjskega narečja štajerske narečne skupine. Leksem bratan se kot dvojnica pojavi le v točki na skrajnem vzhodu istrskega narečja. Različico bratič poznajo tri točke na skrajnem JV štajerske narečne skupine: srednještajerskega in kozjanskega narečja na meji s Hrvaško (338-340).

Drugo najpogostejše poimenovanje je strnič. Značilen je za primorsko narečno skupino (jugovzhodni del kraškega narečja, istrsko in notranjsko narečje),

3 Povzeto po Bezlaj (1977, 38, 1995, 230, 330-331), Pleteršnik (2006), Skok (1971, 199200) in Snoj (2003, 54-55, 651).

4 Ravnik (1996, 267).

5 Slovenski etnološki leksikon $(2004,274)$ in Pirona $\left(2001^{2}, 181\right)$.

6 Kot obliko zermán (ž. zermána) leksem najdemo v Slovenskem etnološkem leksikonu $(2004,707)$ in v Bezlaj $(2005,406)$.

7 Slovenski etnološki leksikon $(2004,654)$. 
točka rovtarskega črnovrškega narečja ter laški govor posavskega narečja in kozjansko-bizeljsko narečje štajerske narečne skupine. Leksem strnična imamo na jugozahodu primorske (kraško in notranjsko narečje) ter ločeno še na jugovzhodu štajerske narečne skupine (posavsko in kozjansko-bizeljsko narečje). Različico s pripono -ka (strnička) najdemo le na zahodu: kot dvojnico v točki kraškega narečja in v notranjskem narečju primorske narečne skupine ter v točki črnovrškega narečja rovtarske narečne skupine.

Leksem sestrič poznajo v Celju in okolici (v srednjesavinjskem, srednještajerskem in južni polovici južnopohorskega narečja štajerske narečne skupine), kot dvojnico pa še v točki na skrajnem severovzhodu severnopohorsko-remšniškega narečja koroške narečne skupine. Manj razširjen je leksem sestričen; najdemo ga v točki ziljskega narečja koroške narečne skupine, kot dvojnico pa še v točki zagorsko-trboveljskega govora in dveh točkah srednjesavinjskega narečja. Leksem sestranec se pojavi le enkrat, še takrat kot dvojnica: v točki na zahodu prekmurskega narečja. Poimenovanje sestrička imajo le v dveh točkah na skrajnem severu podjunskega narečja $(32,33)$.

Razlikovanje bratran(ec) s pomenom 'stričev sin' in sestrič(en) s pomenom 'tetin sin', torej po sestri in bratu (očeta ali mame), je zabeleženo v zagorsko-trboveljskem govoru, srednjesavinjskem, srednještajerskem in južnopohorskem narečju štajerske narečne skupine ter $\mathrm{v}$ točki na skrajnem severovzhodu koroške narečne skupine. To razlikovanje se je začelo mešati z bratran(ec) s pomenom 'bratranec po očetu' in sestrič(en) s pomenom 'bratranec po mami', torej po mami in očetu, ne pa po sestri in bratu. Tako so po očetovi strani bratranci in bratranke, po mamini pa sestriči in sestrične (v Velenju in okolici). Razlikovanje sestrična in bratran(č) ka poznajo štajerska zgornjesavinjsko, srednjesavinjsko in srednještajersko narečje ter točka na skrajnem vzhodu podjunskega narečja, točka na vzhodu mežiškega narečja ter točki na zahodu severnopohorsko-remšniškega narečja koroške narečne skupine.

Leksem bratranka je značilen za severovzhod: vzhodni del koroške narečne skupine in severozahodni del štajerske narečne skupine (zgornje- in srednjesavinjsko narečje). Pomanjševalnica bratrančka obstaja kot dvojnica le v dveh točkah koroškega severnopohorsko-remšniškega narečja. Malce bolj razširjen je v koroški narečni skupini izraz bratrančinja, in sicer v rožanskem, obirskem in podjunskem narečju. Leksem bratana se kot dvojnica pojavi le v točki na skrajnem vzhodu istrskega narečja.

Opisna poimenovanja ta mali brat ali mali brat najdemo le v dolenjski narečni skupini: v točki 237 (tåo mâl brạ̈t), kot drugi leksem (poleg bratranec) pa še v točkah 256 (ta mâl brät), 258 (ta mâl brät) in 279 (mâlę brät). Tudi opisno poimenovanje (ta) mala sestra najdemo le v dolenjski narečni skupini: v točki 237 (ta mâta sięstra), kot drugi leksem (poleg sestrična) pa se pojavi še v točkah 234 (tị mâla siệstra), 238 (to mầta siéstra), 256 (ta mâta seấstra) in 279 (mâlla siệstra).

Na obrobju slovenskega etničnega prostora se uporabljajo prevzete besede. Romanski različici kužin in kužina se pojavita samo na zahodnem robu slovenskega jezikovnega prostora: v rezijanskem, terskem, nadiškem in briškem narečju, banjškem govoru ter severnem delu kraškega narečja, kjer poleg romanske najdemo tudi 
slovensko dvojnico - bratranec. Različico kusen, kusena pozna le točka na jugu ziljskega narečja. Romanizem zurman, zurmana se pojavi v eni sami točki na skrajnem zahodu istrskega narečja (ob obali). Na vzhodu se samo v eni točki pojavi iz madžarščine prevzeta beseda unokateštver: kot dvojnico (poleg leksema bratranec) jo najdemo na severu prekmurskega narečja, v madžarskem Porabju.

\section{Viri in literatura}

Arhiv Dialektološke sekcije Inštituta za slovenski jezik Frana Ramovša, ZRC SAZU, Ljubljana, Listkovno in zvezkovno gradivo za Slovenski lingvistični atlas (SLA) za vprašanji št. 626 in 627.

Benedik, Francka, 1999, Vodnik po zbirki narečnega gradiva za Slovenski lingvistični atlas (SLA), Ljubljana, Založba ZRC (ZRC SAZU).

Bezlaj, France, 1977, 1995, 2005, Etimološki slovar slovenskega jezika I, III, IV Ljubljana, Mladinska knjiga.

Hradil, Jože, 1996, Slovensko-madžarski slovar = Szlovén-magyar szótár, Ljubljana, DZS.

Logar, Tine \& in Rigler, Jakob, 1993, Karta slovenskih narečij, Ljubljana, MK (zemljevid).

Logar, Tine, 1996, Dialektološke in jezikovnozgodovinske razprave (ur. Karmen Kenda-Jež). Ljubljana: ZRC SAZU, Inštitut za slovenski jezik Frana Ramovša.

Pirona, Giulio, 2001², Il nuovo Pirona: vocabolario friulano, Udine, Societa filologica friulana.

Pleteršnik, Maks, 2006, Slovensko-nemški slovar I-II, CR-ROM, Transliterirana izdaja, Uredila M. Furlan (Original izšel 1894-5), Ljubljana, Založba ZRC, ZRC SAZU.

Ravnik, Mojca, 1996, Bratje, sestre, sestriči, zermani: družina in sorodstvo v slovenski Istri, Ljubljana: Založba ZRC (ZRC SAZU).

SSKJ (Slovar slovenskega knjižnega jezika), Založba ZRC, ZRC SAZU, Inštitut za slovenski jezik Frana Ramovša, Ljubljana, 1995.

Slovenski etnološki leksikon (ur. Angelos Baš), 2004, Ljubljana, Mladinska knjiga.

Snoj, Marko, 2003, Slovenski etimološki slovar, Ljubljana, Modrijan.

Skok, Petar, 1971-1973, Etimologijski rječnik hrvatskoga ili srpskoga jezika I-III, Zagreb, Jugoslavenska akademija znanosti i umjetnosti.

\section{Vocabulary Denoting "cousin" in Slovenian Dialects (Using Material for the SLA)}

Summary

An analysis of names denoting the children of uncles or aunts shows considerable dialect diversity, which is the result of various phonological and word-for- 
$4 \quad$ mative development processes in Slovenian dialects. On the periphery in particu[I lar, this is also the result of language contact. The forms bratranec 'male cousin' $\mathrm{N}$ and sestrična 'female cousin' are found throughout most Slovenian territory. The $\rightarrow \quad$ second most frequent terms are strnič and strnična/strnička. The majority of other 그 dialect lexemes for 'male cousin' and 'female cousin' are also of Slovenian origin; they only differ in the word-formative suffixes used with the bases brat(r)- or sestr(i.e., -an, -ec, -ič, -en; -a, -(a)na, -ica, -in-ka, -an-ka, -an-čka, an-činja, -ič-na, and -ič-ka). Names referring to the children of uncles or aunts are thus interesting not only because of these various lexemes, but primarily because of the great variety of word-formative affixes in Slovenian dialects. This is also demonstrated by certain forms that cannot be found in dictionaries (for example, sestranica and sestrinka, or bratrančka and bratrančinja).

In terms of loanwords, the lexemes kužin-a, kusen-a, and zurman-a appear in the west, borrowed from Italian or Friulian (the word-formative morphemes of these loan words are, however, Slovenian). The vocabulary is presented through linguistic geography; lexical and word-formative maps demonstrate the spatial distribution of names denoting 'male cousin' and 'female cousin' in Slovenian dialects. The texts accompanying the maps present their frequency and differentiation-for example, the differentiation in Styrian dialects between bratran(ec) 'uncle's son' and sestrič(en) 'aunt's son', which has begun mixing with the differentiation between bratran(ec) 'paternal male cousin' and sestrič(en) 'maternal male cousin'.

\section{Priloga:}

Leksično-besedotvorni karti:

Karta št. 1 - SLA V626 (bratranec)

Karta št. 2 - SLA V627 (sestrična)

Tjaša Jakop

Inštitut za slovenski jezik Frana Ramovša ZRC SAZU

Novi trg 2, 1000 Ljubljana

jakop@zrc-sazu.si 


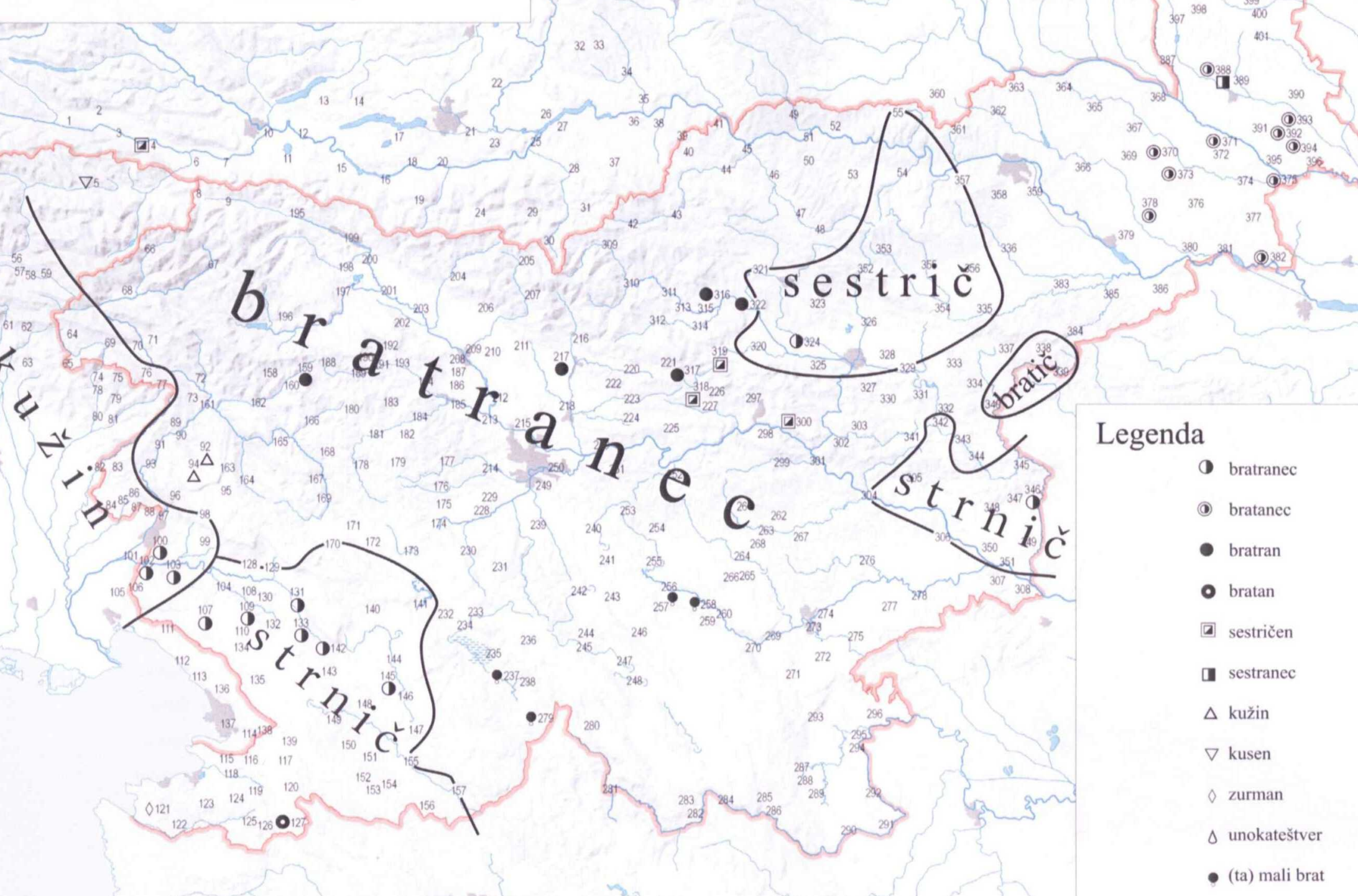



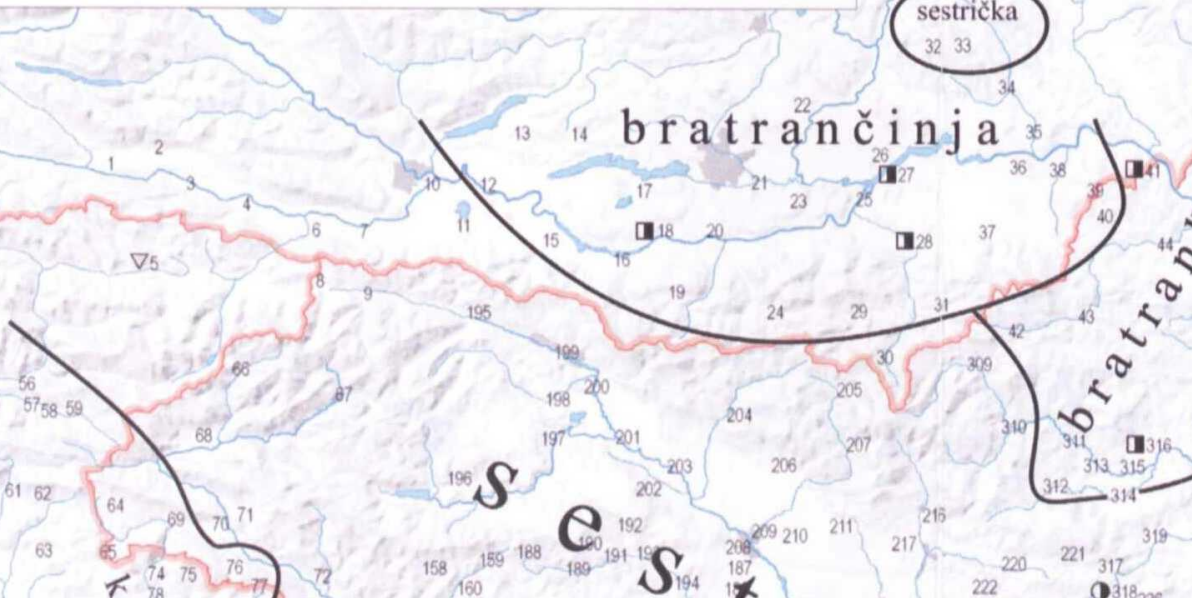

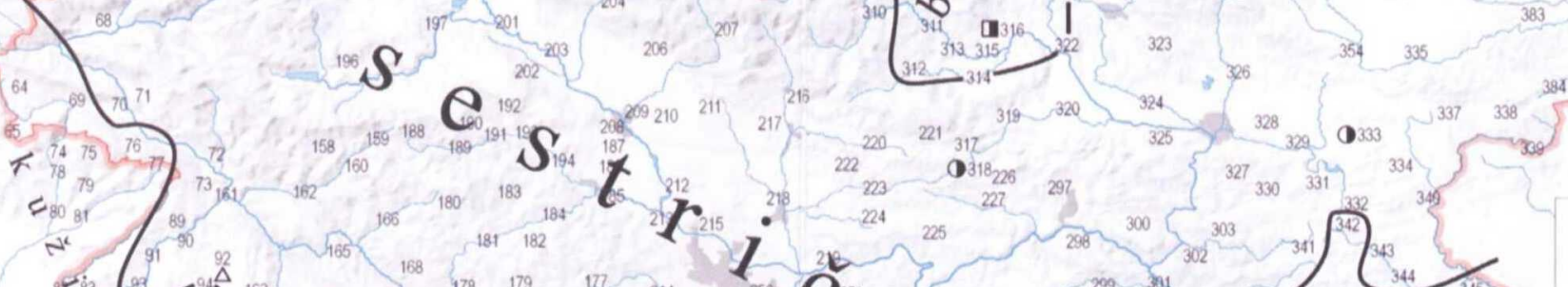
S. $\quad 1$ (3.
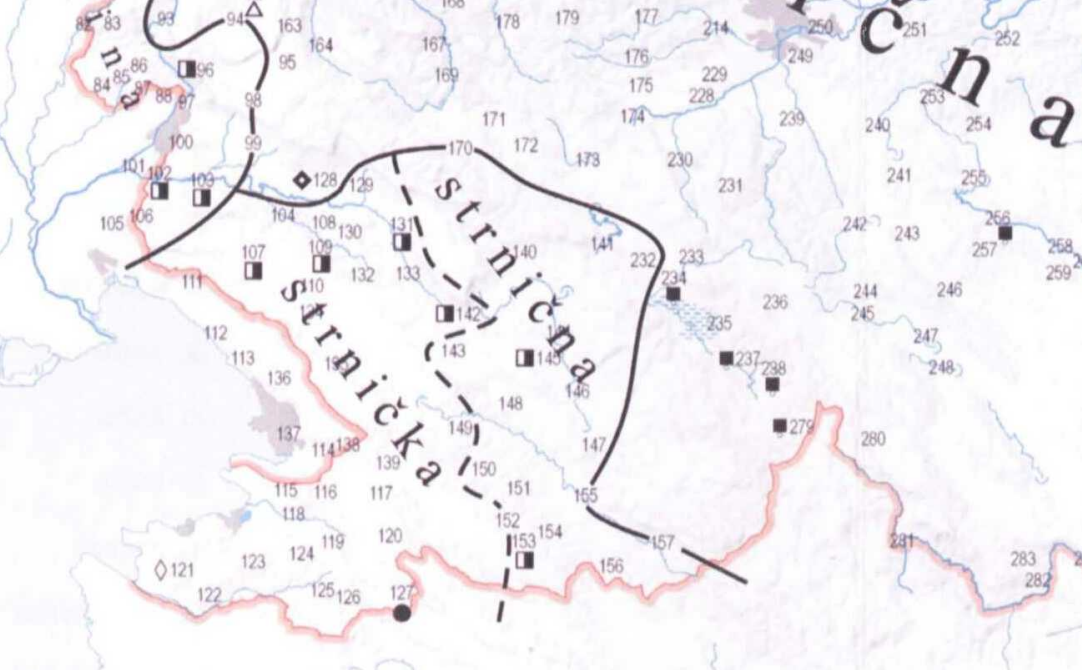

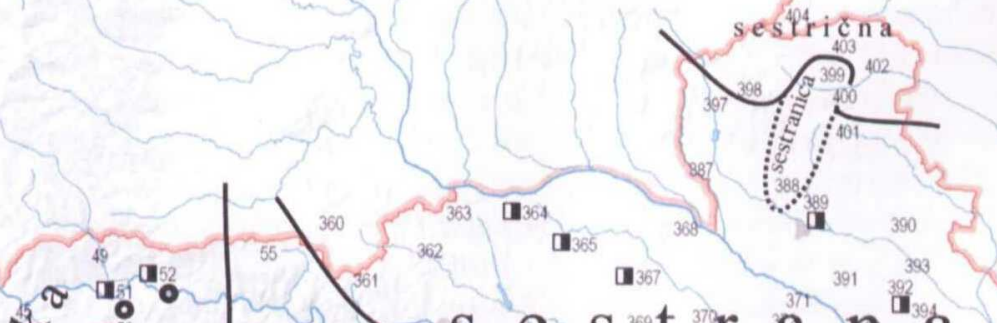
$\left.\sigma^{2}\right|_{4} ^{-10}$

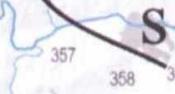

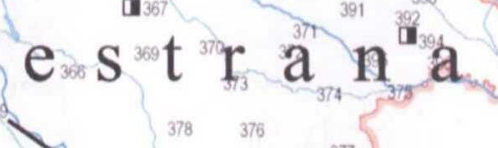

\section{Legenda}

[ sestrična

- sestrinka

- bratranka

- bratrančka

- bratana

- strnicka

$\Delta$ kužina

$\nabla$ kusena

¿ zurmana

- (ta) mala sestra 